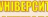

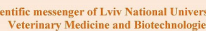

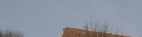

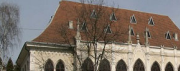

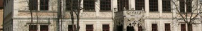

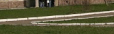

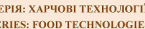
Том 21 № 91
Науковий вісник Яьвівського національного університету ветеринарної медицини та біотехнодогій імені С.3. Гжицького. Серія: Харчові технології

\author{
Scientific Messenger of Lviv National University
} of Veterinary Medicine and Biotechnologies.

Series: Food Technologies

UDC 637.5.05/07:637.56

\title{
Investigation of organoleptic and functional-technological parameters of meat breads using mechanically deboned poultry meat
}

\author{
V.I. Tischenko ${ }^{1}$, N.V. Bozhko ${ }^{1}$, V.M. Pasichnyi ${ }^{2}$, V.V. Brazhenko ${ }^{1}$ \\ ${ }^{1}$ Sumy National Agrarian University, Sumy, Ukraine \\ ${ }^{2}$ National University of Food Technologies, Kyiv, Ukraine
}

\section{Article info}

Received 07.01.2019

Received in revised form 11.02 .2019

Accepted 12.02.2019

Sumy National Agrarian University, G. Kondratieva Str., 160, Sumy, 40021, Ukraine. Tel.: +38-054-270-11-43. E-mail: tischenko_1958@ukr.net natalybozhko@ukr.net

National University of Food Technologies, Volodumurska Str. 68, Kyiv, 01601, Ukraine. Tel.: +38-067-661-11-12 E-mail:pasww1@ukr.net
Tischenko, V.I., Bozhko, N.V., Pasichnyi, V.M., \& Brazhenko, V.V. (2019). Development of meatcontaining semi-smoked sausages with Muscovy duck meat and white carp. Scientific Messenger of Lviv National University of Veterinary Medicine and Biotechnologies. Series: Food Technologies, 21(91), 3-8. doi: 10.32718/nvlvet-f9101

Creation of combined meat products combining traditional consumer properties, as well as the possibility of using non-traditional raw materials in their recipes, is aimed at the expansion and rational use of the raw material base of the meat processing complex and solves the problem of reducing nutrient deficien$c y$ in the diet of the population. Therefore, the issue of the use of mechanically deboned poultry meat in meat bread technology and its impact on qualitative indicators and functional and technological properties is relevant. The aim of the research was to study the feasibility of the use of mechanically deboned poultry meat in the technology of combined products. Three model recipes based on the formula-meat analogue "Chainyyi" were developed. The possibility of replacing beef and pork meat with duck meat and mechanically deboned poultry meat of turkey was studied in the bread recipes. The total amount of duck meat and mechanically deboned poultry meat was $63 \%$. As a protein ingredient able to bind moisture and relatively inexpensive compared to meat raw material, $20 \%$ of the pig's heart was added to the formulation, as well as $2 \%$ XB Fiber. Other components of the analogue formulation have not changed. Combination of duck meat with mechanically deboned poultry meat of turkey and pork hearts in the abovementioned ratios as part of meatcontaining bread stuffing systems allowed to improve the nutritional value of the product and its qualitative indices. The research confirmed the possibility of combining regional and relatively cheap raw materials to increase the nutritional value of meatcontaining products, namely breads. The bulk of proteins in the experimental samples increased by $6.57-10.38 \%$ and was within the range of 17.96-17.34\%. On average, $4.98 \%$ decreased the fat content, the product became less calorie relative to the analogue by 15.98 $16.76 \%$. The formulations of model minced meat were distinguished by a higher index of the water-holding capacity, the content of binding moisture and the best indicators of plasticity. This affected the quantity of finished products, which amounted to $120.64-117.3 \%$ to the mass of raw materials, while in the control sample this figure was lower by 3.49-7.47\%.

Key words: duck meat, mechanically deboned poultry meat of Turkey, meatcontaining bread, combined product, recipes, functional and technological properties.

\section{Дослідження органолептичних та функціонально-технологічних показників м'ясних хлібів із використанням м'яса птиці механічного обвалювання}

\author{
B.І. Тищенко ${ }^{1}$, Н.В. Божко ${ }^{1}$, В.М. Пасічний르, В.В. Браженко ${ }^{1}$ \\ ${ }^{1}$ Сумський наиіональний аграрний університет, м. Суми, Украӥна \\ ${ }^{2}$ Наиіональний університет харчових технологій, м. Київ, Україна
}

Створення комбінованих м'ясопродуктів, щุо поєднують традиційні споживчі властивості, а також можливість використання нетрадиційної сировини в їхніх рецептурах, спрямована на розщирення $і$ раціональне використання сировинної бази м'ясопереробного комплексу та вирішує проблему зменшення дефіциту нутрієнтів в раціоні харчування населення. Тому є актуа- 
льним питання застосування МПМО в технології м'ясних хлібів та його вивчення впливу на показники якості та функиіональнотехнологічні властивості. Метою досліджень було вивчення можливості застосування МПМО у технологї комбінованих виробів. Було розроблено три модельні рецептури на основі рецептури-аналогу м'ясного хліба “Чайний”. Було вивчено можливість заміни у складі рецептури м'ясного хлібу “Чайний” м'яса яловичини та свинини на м'ясо качки та м'ясо птиці механічного обвалювання індиче. Загальна кількість м'яса качки та МПМО становила 63\%. Як білковий інгредієнт, здатний зв'язувати вологу, та відносно недорогий порівняно з м'ясною сировиною до рецептури додавали 20\% свинячого серия, а також клітковину ХВ Fівег в кількості 2\%. Інші складові рецептури-аналогу не змінювались. Комбінування м'яса качки з МПМО індичим та свинячого серия в наведених співвідношеннях у складі фаршевих систем м'ясомістких хлібів дозволило поліпшити харчову цінність продукту та його якісні показники. В результаті досліджень визначено можливість комбінування регіональної та відносно дешевої сировини для підвищення харчової цінності м'ясомістких виробів, а саме хлібів. Масова частка білків у дослідних зразках збільшилась на 6,57-10,38\% i була в межах 17,96-17,34\%. В середньому на 4,98\% зменшився вміст жиру, продукт став менш калорійним порівняно з аналогом на 15,98-16,76\%. Розроблені рецептури модельних фаршів відрізнялися вищим показником ВУЗ, вмістом зв'язаної вологи та крацими показниками пластичності. Це вплинуло на вихід готових виробів, який становив 120,64-117,3\% до маси сировини, в той час як у контрольному зразку цей показник був нижче на 3,49-7,47\%.

Ключові слова: м'ясо качки, м'ясо птиці механічного обвалювання індиче, м'ясо-місткий хліб, комбінований продукт, рецептури, функціонально-технологічні властивості.

\section{Вступ}

Науковою основою сучасної стратегії виробництва продуктів харчування $є$ пошук нових ресурсів сировини, які б забезпечували оптимальне для організму співвідношення хімічних компонентів їжі. Основним моментом цієї стратегії є пошук нових джерел білків та раціональне використання наявних його ресурсів. Нова ідеологія в цьому напрямку полягає у виробництві комбінованих м'ясопродуктів за умови взаємозбагачення їхнього складу, поєднання функціональнотехнологічних властивостей сировини, підвищення біологічної цінності та органолептичних показників готових виробів та зменшення собівартості.

Розробляючи нові рецептури комбінованих продуктів харчування, варто враховувати сучасні світові концепції "Clean Label", "Functional foods development”, “Organic" та ін., головним пріоритетом яких є мінімізація синтетичних добавок та інгредієнтів, та максимальне і ефективне використання сировини, насамперед регіонального виробництва (Marco, 2017).

В зв'язку з цим важливого значення набуває технологія комплексної переробки доступної вітчизняної сировини, впровадження якої дозволить зменшити залежність від кон'юнктури зовнішнього ринку, більш ефективно використовувати вторинну та малоцінну сировину, знизити собівартість та підвищити ефективність виробництва м'ясопродуктів.

М'ясо птиці за останні декілька років стало одним iз найбільш популярних видів сировини для підприємств м'ясної промисловості. Проте під час переробки птиці виділяють найбільш цінні частини тушок та використовують для копчення, запікання чи реалізації в охолодженому стані. При цьому накопичується сировина зі значно меншим вмістом м'язової тканини, яку краще використовувати для механічного обвалювання (Pereira et al., 2011). В м'ясі птиці механічного обвалювання (МПМО) високої якості вміст м'язової тканини може сягати 65-68\%. У випадку низької якості вихідної сировини кількість м'язової тканини іноді не перевищує 10-12\% (Pereira et al., 2011; Horita et al., 2014).

У зв'язку зі збільшенням обсягів використання МПМО в м'ясних продуктах актуальним є питання його функціональних властивостей. Основна частина
МПМО використовується у виробництві емульгованих продуктів харчування, передовсім варених ковбас (Bozhko et al., 2016; Bozhko et al., 2017).

В літературних джерелах (Mielnik et al., 2002; Darosa et al., 2005) є свідчення, що кращі емульгуючі та водо утримуючі властивості мають фаршеві системи, до яких входить МПМО та м'ясо птиці ручного обвалювання. На думку дослідників оптимальним вмістом МПМО в рецептурах складає 25-30\%.

В той же час доведено, що емульгуючі властивості МПМО знижуються при збільшенні у вихідній сировині включень шкіри. Як відомо, МПМО має підвищений показник $\mathrm{pH}$ порівняно 3 іншими видами м'ясної сировини, що також позитивно впливає на емульгуючі властивості та стабільність емульсії фаршів.

Механічне обвалювання м'яса птиці впливає на колір м'ясної маси після сепарування. В процесі сепарування в м'ясо потрапляють гемові пігменти із кісткового мозку. В результаті їх вміст зростає в 2,5-3 рази порівняно з м'ясом ручного обвалювання. Як наслідок, в продуктах, що містять МПМО, можуть виникати дефекти кольороутворення. Продукти можуть набувати відтінків від зеленуватого до темнобурого кольору. Отже, це питання є досить важливим та потребує додаткового вивчення та аналізу (Sjems, 2007; Melnik et al., 2011).

Беручи до уваги нестабільний хімічний склад та функціонально-технологічні властивості МПМО необхідно розробити заходи щодо їх стабілізації, в першу чергу шляхом комбінування із сировиною, що має кращі технологічні характеристики. Проведені попередні дослідження (Thomsen \& Zeuthen, 1988; Pasichnyi et al., 2016) довели доцільність поєднання традиційних видів м'яса з МПМО при виготовленні ковбасних виробів та напівфабрикатів. Проте в літературних джерелах досить мало інформації щодо застосування МПМО в технології м'ясних хлібів та його впливу на якісні показники та функціональнотехнологічні властивості.

Метою наших досліджень було вивчення можливості застосування МПМО у технології комбінованих виробів, а саме м'ясомістких хлібів. Відповідно до мети були поставлені такі завдання: 
- $\quad$ дослідити вплив різної відсоткової частки МПМО в рецептурі на функціонально-технологічні властивості комбінованих фаршевих систем;

- $\quad$ дослідити якісні показники та показники безпечності готових виробів;

- $\quad$ в залежності від отриманих результатів відпрацювати рецептуру комбінованих м’ясомістких хлібів.

\section{Матеріал і методи досліджень}

Об’єктом досліджень було МПМО індиче, виготовлене відповідно ДСТУ 46.070-2003 на ТОВ “Сумський бекон” ТМ “Своя індичка" в Сумській області. Для вирішення поставлених завдань як рецептуру аналогу обрали м'ясний хліб “Чайний” (ДСТУ 4436:2005) (DSTU 4436:2005, 2006). Варіанти рецептур наведені в таблиці 1 .

\section{Таблиця 1}

Рецептури дослідних зразків м'ясомістких хлібів

\begin{tabular}{lcccc}
\hline \multicolumn{1}{c}{ Інгредієнти } & Контроль (аналог) & Варіант 1 & Bаріант 2 & Bаріант 3 \\
\hline Яловичина 2 сорту & 70 & - & - & - \\
Свинина напівжирна & 20 & - & - & - \\
М'ясо качки & - & 25 & 30 & 35 \\
Серце свиняче & - & 20 & 20 & 20 \\
МПМО індиче & - & 38 & 33 & 28 \\
Шпик боковий & 8 & 10 & 10 & 10 \\
Борошно пшеничне & 2 & 2 & 2 & 2 \\
ХВ Fiber & - & 2 & 3 & 3 \\
Меланж & - & 1,5 & 1,5 & 1,5 \\
Сіль кухонна & 1,5 & 0,0075 & 0,0075 & 0,0075 \\
Нітрит натрію & 0,0075 & 0,1 & 0,1 & 0,1 \\
Чорний перець мелений & 0,1 & 0,1 & 0,1 & 0,1 \\
Цукор & 0,1 & 0,05 & 0,05 & 0,05 \\
Коріандр мелений & 0,05 & 0,2 & 0,2 & 0,2 \\
Часник свіжий & 0,2 & & & \\
\hline
\end{tabular}

В процесі досліджень визначали можливість заміни у складі рецептури м'ясного хлібу “Чайний” м'яса яловичини та свинини на м'ясо качки та м'ясо птиці механічного обвалювання індиче. Загальна кількість м'яса качки та МПМО становила 63\%. Як білковий інгредієнт, здатний зв'язувати вологу, та відносно недорогий порівняно 3 м'ясною сировиною до рецептури додавали $20 \%$ свинячого серця, а також клітковину XB Fiber в кількості 2\%. Інші складові рецептури-аналогу не змінювались. В результаті такої заміни та комбінування складових у відповідних відсотках відбулася зміна класифікації виробів 3 м'ясних на м'ясомісткі. Приготування фаршу та формування виробів проводили згідно з прийнятою технологією. Кількість доданих спецій, прянощів та інших інгредієнтів, передбачених рецептурою, не змінювали. Виключенням була тільки кухонна сіль, кількість якої зменшували на $0,3 \%$ у зв'язку із наявністю іiі в МПМО.

У модельних зразках м'ясомістких хлібів визначали комплекс якісних та функціонально-технологічних властивостей згідно зі стандартними методиками та проводили органолептичну оцінку (Kyshenko et al., 2010).

Абсолютну похибку вимірювань визначали за допомогою критерію Стьюдента, довірчий інтервал $\mathrm{P}=0,95$, кількість повторів у визначеннях 3-4, кількість паралельних проб дослідних зразків - 3 .

\section{Результати та їх обговорення}

Враховуючи специфіку запропонованої сировини, були проведені дослідження впливу ії частки у рецептурі на харчову цінність, результати дослідження наведені в таблиці 2.

Аналізуючи отримані результати, варто відмітити, що співвідношення білок-жир в дослідних зразках $є$ близьким до одиниці. Таке співвідношення є оптимальним для максимального забезпечення як структурних, так і енергетичних потреб дорослої людини 3 помірно активним способом життя.

Таблиця 2

Якісні показники модельних м'ясних систем до термообробки

\begin{tabular}{lrrrr}
\hline \multicolumn{1}{c}{ Показники } & Аналог & Зразок 1 & 3разок 2 \\
\hline Масова частка вологи, \% & $69,19 \pm 2,88$ & $79,81 \pm 4,12$ & $79,26 \pm 3,88$ & $75,37 \pm 4,02$ \\
Масова частка білку, \% & $16,27 \pm 0,12$ & $17,96 \pm 0,32$ & $17,34 \pm 0,10$ & $17,76 \pm 0,10$ \\
Масова частка жиру, \% & $25,31 \pm 0,80$ & $20,41 \pm 0,30$ & $19,87 \pm 0,42$ & $19,09 \pm 0,26$ \\
Масова частка вуглеводів, \% & $0,97 \pm 0,09$ & $1,03 \pm 0,37$ & $1,03 \pm 0,37$ & $1,03 \pm 0,37$ \\
Пластичність, см ${ }^{2}$ г & $11,67 \pm 0,22$ & $19,10 \pm 0,32$ & $16,31 \pm 0,44$ & $14,32 \pm 0,20$ \\
Співвідношення вода:білок & 4,20 & 4,44 & 4,57 & 0,87 \\
Співвідношення білок:жир & 0,64 & 0,87 & 24 \\
Енергетична цінність, ккал & 298,23 & 257,13 & 25,67 \\
\hline
\end{tabular}


Співвідношення вода-білок в усіх зразках було високим 4,2-4,57 порівняно з оптимальним для даного виду продукту, яке перебуває в межах від 3,0 до 3,5. Проте таке співвідношення не слід розглядати як критичне на цій стадії технологічного процесу. Частина вологи буде випаровуватись під час теплової обробки, а саме протягом 150 хв при температурі 130 $150{ }^{\circ} \mathrm{C}$.

Пластичність фаршевої системи є показником можливості утворення коагуляційної в'язко-пластичної структури, характерної для сирого фаршу. В даному випадку дослідні зразки 1 та 2 мали більш високий показник пластичності порівняно з контролем та зразка 3. Кращі показники пластичності фаршу отримані в дослідних зразках, на нашу думку, пов'язані зі збільшенням кількості сполучнотканинних білків у складі модельних м'ясомістких систем із МПМО індичим. Відбулося підвищення гідрофільних властивостей за рахунок наявності диспергованих колагенових волокон та відповідно виникнення нових реакційноактивних зв'язків.

У таблиці 3 наведено результати дослідження функціонально-технологічних показників модельних фаршів.

Із наведених даних можна зробити висновок, що збільшення в рецептурах дослідних зразків МПМО (індичого) позитивно вплинуло на ВУЗ (вологоутримуючу здатність) фаршу. Так, при додаванні $38 \%$ МПМО цей показник складав 64,07\%, що на 4,3 i 11,8\% вище порівняно з показниками дослідних фаршів та на 24,9\% вище, ніж в контрольному зразку.

Таблиця 3

Функціонально-технологічні властивості модельних фаршів

\begin{tabular}{lrrrr}
\hline \multicolumn{1}{c}{ Показники } & \multicolumn{1}{c}{ Аналог } & \multicolumn{1}{c}{ Зразок 1 } & \multicolumn{1}{c}{ Зразок 2 } & Зразок 3 \\
\hline В33, \% до маси фаршу & $70,39 \pm 0,08$ & $78,54 \pm 0,13$ & $80,03 \pm 0,06$ & $72,54 \pm 0,13$ \\
В33а, \% до загальної вологи & $90,06 \pm 0,30$ & $97,73 \pm 0,03$ & $97,61 \pm 0,78$ & $96,97 \pm 0,03$ \\
ВУ3, \% & $51,28 \pm 4,18$ & $64,07 \pm 4,13$ & $63,79 \pm 3,76$ & $57,30 \pm 3,47$ \\
pH & $5,93 \pm 0,01$ & $6,32 \pm 0,07$ & $6,41 \pm 0,33$ & $6,25 \pm 0,20$ \\
Емульгуюча здатність, \% & $86,03 \pm 0,02$ & $97,00 \pm 1,18$ & $96,00 \pm 0,07$ & $93,05 \pm 1,07$ \\
Стабільність емульсії, \% & $57,14 \pm 1,16$ & $63,04 \pm 1,13$ & $63,27 \pm 1,09$ & $61,37 \pm 1,04$ \\
\hline
\end{tabular}

Аналіз отриманих результатів свідчить, що рН досліджуваних зразків фаршу характеризує їх як доброякісні (оптимальне значення рН для цієї групи виробів становить 5,8-6,4). Доведено, що додавання фаршу МПМО індичого кількості $38,0 \%$ та 33,0\% від загальної маси дозволяє отримати більш в'язку емульсію, стабільність якої є вищою на 10,3\% порівняно 3 контрольним зразком. На нашу думку, це пов'язано $з$ тим, що даний вид сировини містить меншу кількість солерозчинних білків. В такому разі в процесі приготування фаршу гідрофобні групи, що входять до складу білкової молекули особливо водорозчинних білків, інкапсулюють жирову фракцію та утворюють навколо неї білкову структуровану оболонку і забезпечують стабільність фаршевих систем. Ця теорія була підтверджена результатами попередніх досліджень під час розробки комбінованих м'ясопродуктів (Huda et al., 2011; Strashynskyi et al., 2016).

Водозв'язуюча здатність (В33 $\mathrm{a}$ і $\left.333_{\mathrm{m}}\right)$ в усіх зразках була достатньо високою і перевищувала рекомендований для цієї групи виробів (85\%) показник. В33 у дослідних зразках була дещо вищою порівняно 3 контрольним і знаходилась в межах 72,54-80,03\%, а В33 в зразках коливала в межах від 95,06\% до $97,73 \%$. При цьому в дослідних зразках цей показник був вищий на 7,6-8,5\%, ніж в контролі.

Стабілізацію цього показника в розроблених рецептурах можна віднести на рахунок додавання 20\% фаршу, отриманого від тонкого подрібнення свинячого серця, як сировини, що добре утримує вологу в м'ясних системах та надає їм ніжнішої консистенції.

Вихід готових виробів до початкової маси сировини в значній мірі залежить від функціонально- технологічних властивостей білків фаршевої системи, природи білків та технологічних прийомів обробки. Збільшення масової частки вологи у дослідних зразках в середньому на 7,32\% $(6,18-10,62 \%)$ та вищий показник ВУЗ стали причиною більш високого виходу готових виробів після запікання, що відображено на рисунку 1.

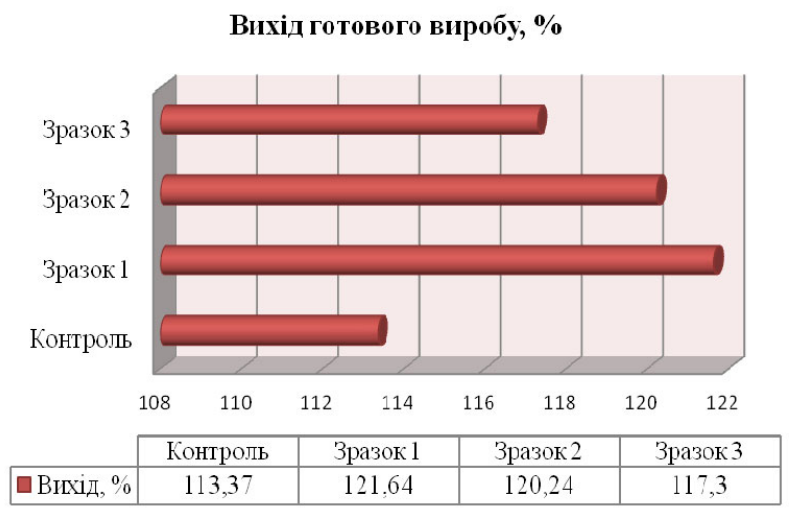

Рис. 1. Вихід готових м’ясомістких хлібів після запікання

Результати сенсорної оцінки розроблених м'ясомістких хлібів наведено на рис. 2.

Введення до складу рецептури МПМО у кількості 38 і 33\% від маси фаршу позитивно вплинуло на функціонально-технологічні властивості фаршу і готових виробів, дає можливість зменшити втрати під час теплової обробки та покращує органолептичні показники. Використання м’яса качки, МПМО індичого та м'язової тканини серця свинячого як замінника основної сировини в рецептурі хліба м'ясного “Чайний” 
другого гатунку дозволяє отримати вироби з високими органолептичними показниками, що не поступаються аналогічним характеристикам виробу аналога. Дегустаційна комісія відзначила гарний зовнішній вигляд, приємний смак та запах соковиту консистенцію та відповідний колір виробів.

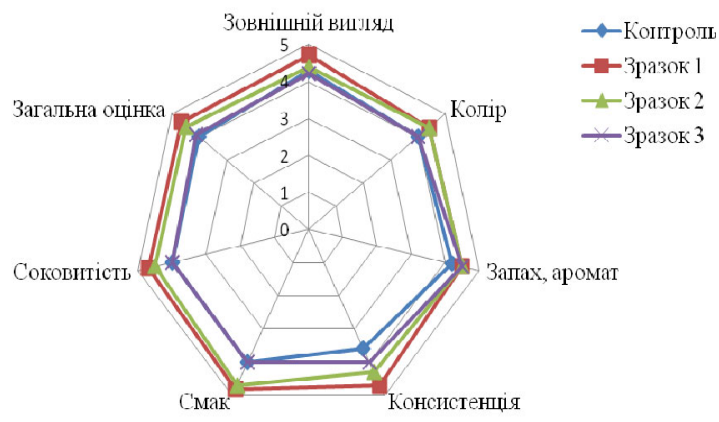

Рис. 2. Результати сенсорної оцінки м'ясомістких хлібів

М'ясомісткий хліб виготовлений за рецептурою 1 та 2 мав найвищі бали практично за всіма показниками. Середня бальна оцінка зразка № 1 складала 4,63 бали, що на $15,4 \%$ вище контрольного зразка та на $12,6 \%$ зразка № 3, виготовленого за подібною рецептурою, але з різним відсотковим співвідношення інгредієнтів.

Специфічність сировини у рецептурі м'ясомістких хлібів викликає ризик мікробіологічного псування, тому було проведено дослідження мікробіологічної безпечності готових виробів. Мікробіологічні показники відповідали вимогам технічного регламенту 021/2011 та вимогам ДСТУ 4432-2005. В усіх зразках бактерій групи кишкової палички в 1 г та патогенних мікроорганізмів, в тому числі Salmonella, в 25 г не виявлено, кількість МАФАМ в середньому складала $1,9 \times 10^{2}$ КУО/1 г, що не перевищує встановлених норм.

\section{Висновки}

Комбінування м'яса качки з МПМО індичим та свинячого серця в наведених співвідношеннях у складі фаршевих систем м'ясомістких хлібів дозволяє поліпшити харчову цінність продукту та його якісні показники.

Підтверджується можливість комбінування регіональної та відносно дешевої сировини для підвищення харчової цінності м'ясомістких виробів, а саме хлібів. Масова частка білків у дослідних зразках збільшилась на 6,57-10,38\% i була в межах 17,9617,34\%. В середньому на 4,98\% зменшився вміст жиру, продукт став менш калорійним порівняно з аналогом на 15,98-16,76\%.

Розроблені рецептури модельних фаршів вирізнялися вищим показником ВУЗ, вмістом зв'язаної вологи та кращими показниками пластичності. Це вплинуло на вихід готових виробів, який становив 120,64$117,3 \%$ від маси сировини, тимчасом як у контрольному зразку цей показник був нижчим на 3,49-7,47\%.
Перспективи подальших досліджень. Метою подальших досліджень $є$ визначення біологічної цінності розроблених виробів та економічної ефективності їхнього виробництва з урахуванням цін на сировину.

\section{References}

Bozhko, N.V., Pasichnyi, V.M., \& Bordunova V.V. (2016). Miasomistki vareni kovbasy z vykorystanniam miasa kachky. Naukovyi visnyk LNUVMBT imeni S.Z. Gzhytskoho, 18, 2(68), 143-146. doi: 10.15421/nvlvet6829 (in Ukrainian).

Bozhko, N.V., Tyshchenko, V.I., Pasichnyi, V.M., \& Miz, Ye.M. (2017). Rozrobka retseptury sardelok z miasa muskusnoi kachky. Prohresyvni tekhnika ta tekhnolohii kharchovykh vyrobnytstv restorannoho hospodarstva i torhivli, 2(26), 94-104. http://elib.hduht.edu.ua/bitstream/123456789/2222/1/ \%2Bsec1_8.pdf (in Ukrainian).

Darosa, F., Massona, M., \& Amicob, S. (2005). The influence of the addition of mechanically deboned poultry meat on the rheological properties of sausage. Journal of Food Engineering, 68(2), 185-189. doi: 10.1016/j.jfoodeng.2004.05.030.

DSTU 4436:2005 (2006) Kovbasy vareni, sosysky, sardelky, khliby miasni. Vydannia ofitsiine. Kyiv, Derzhspozhyvstandart Ukrainy, 31 (in Ukrainian).

Horita, C.N., Messias, V.C., Morgano, M.A., Hayakawa, F.M., \& Pollonio, M.A.R. (2014). Textural, microstructural and sensory properties of reduced sodium frankfurter sausages containing mechanically deboned poultry meat and blends of chloride salts. Food Research International, 66, 29-35. doi: 10.1016/j.foodres.2014.09.002.

Huda, N., Putra, A., \& Ahmad, R., (2011). Potential Application of Duck Meat for Development of Processed Meat Products. Current Research in Poultry Science, 1(1), 1-11. doi: 10.3923/crpsaj.2011.1.11 (in Ukrainian).

Kyshenko, I.I., Starchova, V.M., \& Honcharov, H.I. (2010). Tekhnolohiia miasa ta miasoproduktiv. Praktykum: navch. posibnyk Nats. un-t kharch. tekhnol. Kyiv. NUKhT (in Ukrainian).

Marco, I. (2017). Development of innovative analytical methods for meat products safety and quality assurance: The MPSQA project. J Food Microbiol Saf Hyg, 2(2), 28-34. doi: 10.4172/2476-2059-c1-002.

Melnik, M., Poltsen, K., Overrein, B., Solgaaroe, K., \& Ellekjaer, M. (2011). Quality of mechanically deboned poultry meat of different origins. Proc. XVth European Symposium on the Quality of poultry meat, 9-12 September, Ismir, Tukey, 387-391.

Mielnik, M.B., Aaby, K., Rolfsen, K., Ellekjær, M.R., \& Nilsson, A. (2002). Quality of comminuted sausages formulated from mechanically deboned poultry meat. Meat Science, 61(1), 73-84. doi: 10.1016/S03091740(01)00167-X.

Pasichnyi, V.M., Bozhko, N.V., \& Shalda, I.S. (2016). Otsinka funktsionalno-tekhnolohichnykh vlastyvostei sichenykh napivfabrykativ z miasom kachky. Zbirnyk naukovykh prats: Tekhnika, enerhetyka, transport 
APK. Vinnytskyi natsionalnyi ahrarnyi universytet. VTs VNAU, 4(96), 37-40 (in Ukrainian).

Pereira, A.G.T., Ramos, E.M., Teixeira, J.T., Cardoso, G.P., Ramos, A.L.S., \& Fontes, P.R. (2011). Effects of the addition of mechanically deboned poultry meat and collagen fibers on quality characteristics of frankfurter-type sausages, 89(40), 519-525. doi: 10.1016/j.meatsci.2011.05.022.

Sjems, R.A. (2007). Pererabotka mjasa pticy. Pod red. Alana R.; per. s angl. Pod nauchnoj redakciej Gushhina V.V. SPb. Professija (in Russian).
Strashynskyi, I.M., Fursik, O.P., Pasichnyi, V.M., Marynin, A.I., \& Honcharov, H.I. (2016). Vplyv funktsionalnoi kharchovoi kompozytsii na vlastyvosti miasnykh farshevykh system. Vostochno-evropejskij zhurnal peredovyh tehnologij, 6, 11(84), 53-58. doi: 10.15587/1729-4061.2016.86957 (in Ukrainian).

Thomsen, H.H., \& Zeuthen, P. (1988). The influence of mechanically deboned meat and $\mathrm{pH}$ on the waterholding capacity and texture of emulsion type meat products. Meat Science, 22(3), 189-201. doi: 10.1016/0309-1740(88)90046-0. 